\title{
Outlooks toward Democracy in Quebec
}

\author{
Mebs Kanji, Kerry Lynne Tannahill \\ Concordia University, Montreal, Canada \\ Email: mebs.kanji@concordia.ca
}

Received 7 August 2014; revised 21 September 2014; accepted 5 October 2014

Copyright (C) 2014 by authors and Scientific Research Publishing Inc.

This work is licensed under the Creative Commons Attribution International License (CC BY). http://creativecommons.org/licenses/by/4.0/

(c) (i) Open Access

\section{Abstract}

Support for democratic regime principles is generally strong and stable across advanced industrial democracies. However, as groups of society are becoming increasingly informed and critical and certain segments remain widely and consistently left out or disillusioned, opinions of democracy may suffer. Using a unique dataset (the Comparative Provincial Election Study) with a representative sample of Quebec voters, this analysis provides for the first time a more detailed and focused examination of orientations toward the democratic political regime across three different levels of government (national, provincial, and municipal). Our study reveals that, while most Quebecers feel that a democratic political regime is a good way of governing at all levels of government, only slightly more than a majority commit solely to a democratic alternative and sizeable segments are open to other regime types as well. Also, few Quebecers feel that their democracies are working well in practice at all levels. Our analysis also reveals significant variation in terms of specific support for authorities, institutions of government, and the workings of democracy. More specifically, Quebecers have less confidence in their political leaders than in their elected representatives, more confidence in their legislatures and civil service than in governments and political parties, and they have the lowest confidence in most of these objects at the federal level. Finally, our findings show that these negative orientations toward specific political objects have robust and significant negative effects on the way Quebecers feel about how well their democratic communities are working in practice, even while controlling for other theoretically relevant cultural, structural, and contextual factors.

\section{Keywords}

Political Support, Democracy, Quebec, Comparative Provincial Election Project

\section{Introduction}

Both traditional and more contemporary democratic theory suggests that sustained periods of elevated dissatisfaction toward "specific" political objects, such as political authorities and government institutions, might even- 
tually erode people's broader outlooks toward democracy—otherwise known as regime support (Norris, 2011; 1999; Kornberg \& Clarke, 1992; Easton, 1965). As Norris (2011) describes it:

... substantial and enduring democratic deficits are more commonly regarded with concern, triggering alarm that prolonged and deep disenchantment with the performance of particular political leaders, lack of confidence with governing parties, and disillusionment with core representative institutions will eventually spread upward to corrode faith in democracy itself, like dry rot weakening the foundations from below with the capacity to undermine popular support for fragile democratic regimes (245).

This particular line of reasoning is especially pertinent today because there is now a substantial body of literature which suggests that citizens in contemporary advanced industrial democracies (Canadians and Quebecers included) may be more critical of their political authorities and government institutions than in the past (see for instance Dalton, 2014, 2004; Lenard \& Simeon, 2012; Inglehart, 2007, 1997, 1990; Nevitte \& Kanji, 2002; Norris, 1999; Nevitte, 1996). To this point, we have yet to see much in the way of direct empirical research that looks systematically at the associations between various specific and "diffuse" types of political support ${ }^{1}$. That said, much of the available cross-national and cross-time data that we have suggests that more diffuse support for democracy as a political system has remained fairly stable over time and in some cases even increased (see for example Norris, 2011; Dalton, 2004; Klingemann, 1999). However, more recent evidence indicates that not all citizens in democratic societies believe that their political regimes operate democratically in practice (see for example Norris, 2012, 2011; Nevitte \& White, 2012).

In this paper, we utilize recent evidence from the Quebec variant of the Comparative Provincial Election Project to conduct a more focused and detailed examination of Quebecers' outlooks toward democracy across different levels of government. More specifically, in this investigation we have three main goals. The first is to assess how Quebecers feel about democracy in principle, relative to other prospective regime possibilities, and to compare how democratically they think their political communities are governed in practice? Our second goal is to examine how Quebecers evaluate their political authorities, government institutions and the way their different political systems work overall, as well as to test whether these more specific types of evaluations help to shape how democratically citizens think their political communities operate in practice. Lastly, our third goal is to assess the consistency of our findings across the municipal, provincial and federal political contexts. Much of the cross-national evidence reported to date simply sidesteps the possibility that people's political orientations, especially in multi-level governance regimes such as the Canadian federal political system, may vary across different levels of government. But what does the evidence suggest? Do Quebecers' orientations toward democracy and their respective determinants differ depending on the political context being examined? Or are the findings basically similar regardless of the level of government that we explore?

\section{Theoretical Background}

For a democratic political regime to function efficiently and effectively, and remain free from any stress or potential for interruption, it needs to maintain a sufficient amount of public support (Easton, 1965). Kornberg and Clarke (1992) describe this predicament as follows:

... political leaders in democracies must rely on a fund of positive feelings (support) on the part of citizens rather than on extensive and intensive coercion and indoctrination to sustain their national political communities and regimes and to keep themselves in office. The two principal sources, which we term the "twin pillars" of such support, are the political socialization experiences of citizens, and their judgments about the ability of political figures, institutions and processes to perform their ascribed functions effectively and equitably, and in so doing to provide for national and personal well-being (29).

If for instance, citizens were to "lose confidence in the ability of any authorities at all to cope with the problems of the day, the effect on support to other levels of the system may be very serious, at least for the persistence of that kind of system" (Easton, 1965: 216). In fact, this may well be what happened recently when multiple Canadian Senators were forced to pay back public dollars which they inappropriately expensed. As a result

${ }^{1}$ By "diffuse" support we mean people’s broader orientations toward political regimes (such as democracies, autocracies, etc.) and political communities, such as Canada, Quebec and/or municipalities such as Montreal. Specific support refers to the assessments of "actions and performance” of political objects (Dalton, 2004: 23), “evaluations that reflect judgments about political phenomena” (Dalton, 1999: 59). 
of these actions by Senators, support for the Senate as a political institution has been negatively affected and its continued relevance in the Canadian democratic process rigorously questioned (see for example Hall, 2013 and Payton, 2013).

In the same vein, a loss of support for government institutions may be even more devastating. Norris (2012) for example claims that "any sustained erosion of faith in these institutions has potentially far more serious consequences than does loss of trust in particular presidents, congressional leaders or elected representatives" (35). More specifically, Newton and Norris (2000) have argued in the past that, a "loss of confidence in institutions may well be a better indicator of public disaffection with the modern world because they are the pillars of society. If they begin to crumble, then there is indeed cause for concern" (53). Likewise, recently expanded applications of Easton's earlier framework of political support (see for instance Norris, 2011; 1999; Dalton, 2004; Nevitte, 2002) also incorporate people's overall satisfaction with the workings of democracy as an alternative aggregate determinant of more diffuse regime support. Similar to the logic employed for political authorities and government institutions, the expectation in this case is that the more satisfied citizens are with the overall workings of their democracy, the more likely they are to remain supportive of their current political regime.

To date, much of the observable cross-national and cross-time evidence cumulated and examined on regime support has been mixed. On the one hand, Dalton (2004) and others (such as Klingemann, 1999 for example) claim that support for the democratic political regime in advanced industrial states in general remains strong and in some cases has even increased. "At least in principle”, Dalton (2004) argues, "there is widespread public endorsement of the political values and norms that underlie the democratic process" (40). Moreover, he also reports "that support for the idea of democracy is nearly universal within Western democracies" (41) and that large majorities of publics "feel that democracy is the best form of government even if it has its problems" (41).

On the other hand, Norris (2011) finds that even though support for democratic values (or democracy in principle) is typically strong, not all citizens believe that democracies work democratically in practice. Based on her most recent cross-national and cross-time analysis, Norris reports that there is a notable discrepancy between the degree of importance that people place in democratic rule and the amount of democracy that they feel they receive, particularly in places such as Central and Eastern Europe and in the Middle East, and less so in Scandinavian countries. Similarly, Nevitte and White (2012) have found that "significant subsections of publics... do not think their country is being governed all that democratically" (62). Moreover, their analysis further demonstrates that "evaluations of democratic performance are more divergent than are expressions about the personal importance of democracy" (62).

Likewise, the bulk of the cross-national and cross-time evidence relating to public evaluations of political authorities and institutions is also mixed. Dalton (2014) for example, contends that “... public skepticism about politicians and government officials is spreading to virtually all the advanced industrial democracies” (261), and that support for political institutions such as political parties and parliaments in advanced industrial states has declined. Norris (2011) however, warns that Dalton's evidence needs to be interpreted with due caution:

"trust in political institutions such as national governments, parliaments, and parties displays systematic and persistent contrasts among established democracies in Western Europe and the United States. The longitudinal evidence clearly demonstrates that fluctuations over time usually prove far more common than straightforward linear or uniform downward trends” (241).

Based on her findings, Norris concludes that "the 'crisis' myth, while fashionable, exaggerates the extent of political disaffection and too often falls into the dangers of fact-free hyperbole” (241). Furthermore, Norris goes on to recommend that more detailed investigations are required in order to make better sense of the true extent and nature of the democratic deficit across different contexts (also see Chambers \& Lenard, 2012).

In this paper we aim to act on some of Norris' advice by looking more closely at what one particular subgroup of the Canadian population-Quebecers - think about democracy both in principle (relative to other political regime possibilities) and its application in practice. Also, while most cross-national investigations merely skim the surface by focusing solely on what entire state populations think about their political systems in general, in this investigation, we look in more detail at how Quebecers perceive their respective municipal, provincial and federal political regimes and compare the findings in order to assess whether there are any important sub-state differences to report. In multi-level governance systems such as the Canadian federal political regime, the rules of the game can vary, especially in practice, across different levels of government. As a consequence, it is not unreasonable to assume that this might have some distinguishing implications for people's orientations toward the 
democratic regime across these different political contexts both in principle and in practice.

In addition, in this analysis we look systematically at how supportive Quebecers are of their different political authorities, core government institutions and the workings of their democracy across the different levels of government. We examine whether specific support for these different political objects is consistently and powerfully linked to more diffuse outlooks about democratic governance in practice, while also controlling for a variety of alternative explanations that are considered relevant within the literature (see for example Norris, 2011; Dogan, 2005; Dalton, 2004). For instance, Dalton's (2014) research on cognitive mobilization suggests that because citizens in post-industrial societies are now more educated and engaged in politics than generations before they may have a stronger understanding and conviction about the democratic process. Consequently, it is possible that this translates directly into more positive outlooks toward democratic governance in practice (Welzel, 2013; Norris, 2011; Inglehart \& Welzel, 2005). At the same time, however, there is also the possibility that structural and cultural changes such as these are gradually transforming publics into more critical citizens (see for instance Norris, 1999 or Inglehart, 1997) which may result in negative outcomes for democratic support (see for instance, Norris, 2011). For example, Nevitte (2002) argues that cognitive mobilization and the information explosion (Dalton, 2014; Clark \& Rempel, 1997) are fuelling an efficacy gap, whereby citizens' perspectives of their abilities to be involved in the democratic process outpace their assessments of the political system's ability to respond. This in turn may detract from regime support.

Another related plausibility (see Norris, 2000) suggests that an increase in negative news coverage will take away from people's support for different political objects. Note however that the most recent evidence (see Norris, 2011) shows that "users of television and radio news proved more satisfied with democracy, not less... [and that] regular use of all these media reduced the democratic deficit, or the gap between expectations and perceived performance" (244). Still, there remains the possibility that media coverage has varying effects across different levels of government, and for this reason this explanation still merits more detailed investigation.

In addition, Inglehart's $(2007,1997,1990)$ post-materialist thesis contends that the value priorities of younger generations are not the same as those of their more materialist parents and grandparents (also see, Inglehart \& Welzel, 2005; Nevitte, 1996). One consequence of this transformation is that younger generations with more post-materialist value orientations tend to want to be more directly engaged in democracy than more materialist older generations. This is because post-materialists are not as likely to respect hierarchical authority and are more likely to challenge political elites. In a similar vein, Putnam (2000) claims that younger generations, because they are less socially interactive, are not as likely as previous generations to trust others (including their political authorities). As a result, it is plausible that both post-materialist values and low levels of inter-personal trust are negatively associated with support for democracy in practice.

Next, our investigation also takes into account a few other alternative factors such as the perceived integrity of political authorities and levels of public cynicism, both of which have been linked in the past to variations in political support (see for instance, Kanji \& Tannahill, 2014; Pharr, 2000; Della Porta, 2000; Blais \& Gidengil, 1991). It is particularly important that we control for such determinants given the ongoing Charbonneau Commission $^{2}$ and its various recent revelations about the corruption in Quebec politics and the very real possibility that this process may have contributed to shaping people's perceptions of the integrity of political authorities and to fueling levels of public cynicism at different levels of government (Woods, 2014; CBC, 2013). Finally, our analysis considers various other contextual factors, such as people's political background, their primary language, age, sex, income level and place of birth, all of which have been demonstrated on various occasions in the past to be at least partially associated with different outcomes in Quebec politics (see for example, Blais \& Gidengil, 1991).

\section{Data: The Comparative Provincial Election Project}

The data that we examine in this investigation come from the Comparative Provincial Election Project (CPEP) ${ }^{3}$. This country-wide survey research initiative employs a standardized survey questionnaire to explore Canadians' perceptions toward democracy as well as their electoral inclinations and behavior. Unlike the Canadian Election Studies (CES) ${ }^{4}$, however, the CPEP is administered on a province-by-province basis, which makes it possible

\footnotetext{
${ }^{2}$ For information about the Commission visit their official site at: https://www.ceic.gouv.qc.ca/la-commission.html. For a brief timeline of events from June to December 2012, see http://www.montrealgazette.com/news/charbonneau-timeline.html.

${ }^{3}$ See, http://cpep.ualberta.ca/ for details on this project.

${ }^{4}$ See, http://ces-eec.org/pagesE/home.html for details on this project.
} 
(in some cases more so than others) to conduct more detailed sub-state investigations with larger sample sizes. In addition, the Quebec component of the CPEP is particularly unique in that it is based on an expanded questionnaire that is designed specifically to probe deeper into people's support for democracy in principle and democratic governance in practice as well as their support for different political objects across various levels of government. Moreover, the Quebec study makes it possible to test the variety of alternative explanations of political support that the literature suggests may be salient. In each of these respects therefore, the Quebec component of the CPEP is ideally suited for a more detailed and focused analysis to support our proposed investigation.

It is also important to point out that, unlike other Canadian election surveys that have been conducted in the past, the CPEP is administered entirely online through an internet survey platform licensed by Abacus Data ${ }^{5}$. In addition, these surveys are executed only once after a provincial election has been contested, and not in multiple waves like the more recent CES (see Kanji, Bilodeau, \& Scotto, 2012). Thus, in the case of the 2012 Quebec study, the survey instrument was in the field for slightly more than one month and launched immediately after the September 4th provincial election. Altogether, slightly more than 1000 Quebecers $(n=1010)$ were surveyed and a large proportion of these respondents $(n=728)$ were sampled from an online panel of Canadians which was generated through random phone invitations. The rest of the sample was then randomly solicited through the use of Interactive Voice Response technology ${ }^{6}$. Respondents consist of Quebec residents of voting age.

\section{The Findings \& Discussion}

Our investigation begins with the examination of what Quebecers think about democracy in principle relative to other potential regime alternatives. Similar to much of the cross-national evidence reported to date, the findings in Table 1 suggest that virtually all Quebecers concur that "having a democratic political system" is a "good way of governing". And, at least in Quebec, these data demonstrate that this is a fairly generalizable perspective that consistently re-appears regardless of the level of government (or the political playing field) that we probe about, be it provincial (96\%), federal (95\%), or municipal (95\%). In addition, a more detailed breakdown of these data reveals that the bulk of this support seems to be firmly rooted, where more than three in every four Quebecers feel that "having a democratic political system" is in fact a "very good way of governing" (as opposed to only a "fairly good way of governing"), at each the provincial (78\%) and federal (77\%) levels. At the municipal level, no less than 74\% of Quebecers indicate that they feel the same way. This said, however, observation of attitudes toward alternative regime possibilities suggest that Quebecers may not be fully committed to democracy in principle.

Table 1. Quebecers' orientations toward democracy and other regime alternatives in principle (proportion indicating that the regime alternative presented "is a good way of governing”).

\begin{tabular}{cccc}
\hline Regime alternatives & Province & Country & City/Town \\
\hline Democratic system & $96 \%$ & $95 \%$ & $95 \%$ \\
Very Good & $78 \%$ & $77 \%$ & $74 \%$ \\
Fairly Good & $18 \%$ & $18 \%$ & $21 \%$ \\
Expert rule (not government) & $39 \%$ & $36 \%$ & $42 \%$ \\
Leader rule (no legislatures or elections) & $13 \%$ & $10 \%$ & $11 \%$ \\
Army rule & $2 \%$ & $2 \%$ & $2 \%$ \\
"Committed Democrats" & $54 \%$ & $57 \%$ & $52 \%$ \\
Proportion who feel that only the democratic system "is a good way of governing” & & & \\
\hline
\end{tabular}

Note: Question: The following are various types of political systems. For each one, would you say it is a very good, fairly good, fairly bad or very bad way of governing this PROVINCE/COUNTRY/CITY-TOWN? Having a democratic political system; Having experts, not government, make decisions according to what they think is best for the PROVINCE/COUNTRY/CITY-TOWN; Having a strong leader who does not have to bother with legislatures and elections; Having the army rule”. Source: 2012 Quebec CPEP, n = 1.010.

\footnotetext{
${ }^{5}$ See, http://abacusdata.ca/ for more details on this organization.

${ }^{6}$ See, http://cpep.ualberta.ca/en/CPEPSurvey.aspx for more details on methodology.
} 
For instance, a sizeable number of Quebecers (about two in every five-39\%) indicate that having experts rule, instead of governments, would also be a "good way of governing" the province. Furthermore, nearly the same proportion of Quebecers (36\%) feel that rule by experts would be a "good way of governing" the country. And at the municipal level, support for this particular proposition (42\%) is even greater than at either the federal and provincial levels. The findings also suggest that there is a small but nonetheless noticeable proportion of Quebecers who believe that "having a strong leader who does not have to bother with legislatures and elections" would also be a "good way of governing" at all three levels of government (provincial: $13 \%$, federal: 10\%, and municipal: $11 \%$ ). And there is even a very minor proportion of Quebecers (2\%) who would believe that army rule would be a "good way of governing" at all three levels of government. The key point to take away from these additional observations is that, even though virtually all Quebecers view democratic rule as a good way of governing, only a small majority actually qualify as "committed or dedicated democrats", meaning that they view democracy as the only "good way of governing", regardless of whether it is at the provincial (55\%), federal (57\%) or municipal (52\%) levels. In principle at least, there is a sizeable number of Quebecers who believe that various alternative political systems may also be good for governance.

Table 2 provides an alternative way of assessing how Quebecers feel about their respective democratic regimes across different levels of government by observing their evaluations of democracy in practice. On a scale ranging "from 1 to 10, where 1 means 'not at all democratic' and 10 means 'completely democratic'", what do Quebecers think about the way their provincial, federal and municipal political communities are governed in practice? Note first that the findings in this case are much more varied than support for democratic systems in principle. For example, little more than a majority of Quebecers (52\%) believes that their province is, or comes close to being governed in a "completely democratic" manner (scoring 8, 9, or 10 on a 10-point scale). In other words, about $46 \%$ rate the quality of their provincial democracy as no higher than a 7 on a scale that ranges from 1 to 10. Moreover, Quebecers' assessments of their federal and municipal democracies are even worse. Less than a majority of Quebecers view their federal (42\%) and municipal (45\%) democracies as either approaching or being "completely democratic". Most view their municipal community (53\%) or their federal community (56\%) as no more than "moderately democratic". Note too that across all three levels of governance, there are sizeable proportions of Quebecers who outright rate the quality of the democratic governance that they receive as "not very democratic" or only "somewhat democratic" These findings are especially striking at the federal and municipal levels (province: 19\%, country: 33\%, city/town: 26\%).

These are not the sort of flattering regime assessments that one might expect to see from citizens who have faith in their political systems. So what is it about their respective democracies that Quebecers find troubling? Why is it that some Quebecers view their provincial, federal and municipal democratic regimes as being governed more democratically than others? One possibility is that such variations are a direct reflection of how citizens feel about the conduct of their political authorities. Consider for instance the findings reported in Table 3. These data clearly show that Quebecers have widely differing degrees of confidence in their political authorities (from "no confidence at all" to "a lot a lot of confidence"). They also suggest that Quebecers are far from unanimous in their evaluations of political authorities. Overall, most Quebecers have no more than just "some confidence" in their political leaders and elected representatives (Premier: 87\%, PM: 91\%, municipal leader: 86\%, MNA: 86\%, MP: 90\%, city councilor: 89\%). And very few Quebecers indicate that they have "a lot of confidence" in their political authorities (Premier: 13\%, MNAs: 13\%, PM: 8\%, MPs: 8\%, municipal leaders: $12 \%$, and city councilors: $9 \%$ ). Also, more than a third of the Quebec population typically indicates that they have either "no confidence at all" or "not a lot of confidence" in their political authorities (Premier: 39\%,

Table 2. Quebecers' evaluations of democracy in practice.

\begin{tabular}{ccccc} 
& Not very democratic & Somewhat democratic & Moderately democratic & Completely democratic \\
\hline Province & $6 \%$ & $12 \%$ & $28 \%$ & $52 \%$ \\
Country & $14 \%$ & $18 \%$ & $24 \%$ & $42 \%$ \\
City/Town & $9 \%$ & $16 \%$ & $28 \%$ & $45 \%$ \\
\hline
\end{tabular}

Note: Questions: "How democratically are the following communities being governed today? Using a scale from 1 to 10 , where 1 means "not at all democratic" and 10 means "completely democratic", what would you say about... PROVINCE/COUNTRY/CITY-TOWN?:

"Not Very Democratic" = 1, 2, 3; "Somewhat Democratic" = 4, 5; "Moderately Democratic" = 6, 7; "Completely Democratic" = 8, 9, 10. Source: 2012 Quebec CPEP, $\mathrm{n}=1.010$. 
Table 3. Specific support—Quebecers' evaluations of political authorities.

\begin{tabular}{ccccc}
\hline & $\begin{array}{c}\text { No confidence } \\
\text { at all }\end{array}$ & $\begin{array}{c}\text { Not a lot of } \\
\text { confidence }\end{array}$ & $\begin{array}{c}\text { Some } \\
\text { confidence }\end{array}$ & $\begin{array}{c}\text { A lot of } \\
\text { confidence }\end{array}$ \\
\hline Political Leaders & & & & \\
Provincial (Premier) & $14 \%$ & $25 \%$ & $48 \%$ & $13 \%$ \\
Federal (Prime Minister (PM)) & $30 \%$ & $34 \%$ & $27 \%$ & $8 \%$ \\
Municipal (Leader) & $11 \%$ & $25 \%$ & $50 \%$ & $12 \%$ \\
Elected Representatives & & & & $13 \%$ \\
Provincial (Member of the National Assembly (MNA)) & $7 \%$ & $24 \%$ & $55 \%$ & $8 \%$ \\
Federal (Member of Parliament (MP)) & $6 \%$ & $29 \%$ & $55 \%$ & $5 \% \%$ \\
Municipal (City Councilor) & $8 \%$ & $25 \%$ & $56 \%$ & $9 \%$ \\
\hline
\end{tabular}

Note: Questions: "Please indicate how much confidence you have in the following political authorities". Source: 2012 Quebec CPEP, n $=1.010$.

MNAs: 31\%, MPs: 35\%, municipal leaders: 36\%, city councilors: 33\%). This finding is consistent across political authorities at all levels except in the case of the Prime Minister, where nearly twice as many respondents have little or no confidence at all (64\%). Lastly, these results reveal that citizens' evaluations of their political authorities vary depending on the level of politician that is considered. Quebecers in particular generally have more confidence in their elected representatives (MNA: 68\%, MP: 63\%, city councilor: 65\%) than in their political leaders (Premier: 61\%, PM: 35\%, municipal leader: 62\%), at all three levels of government, and especially at the federal level where there is nearly a 30\% discrepancy between the degree of confidence that citizens have in their MP and in the Prime Minister of the country.

The evidence from all three levels of government presented in Table 4 suggests that Quebecers also vary in their evaluations of core governmental institutions and that only a few Quebecers admit to having "a lot of confidence" in either their governments (provincial: 11\%, federal: 9\%, municipal: $13 \%$ ), parties (provincial: $3 \%$, federal: $3 \%$, municipal: $8 \%$ ), legislatures (provincial: $15 \%$, federal: $13 \%$, municipal: $10 \%$ ) or civil service (provincial: $13 \%$, federal: $13 \%$, municipal: $13 \%$ ). Similar to the findings reported in Table 3, these data indicate that most Quebecers have no more than "some confidence" in their core government institutions (average across provincial/federal/municipal levels for governments: $87 \%$, parties: $94 \%$, legislatures: $86 \%$, and civil service: 85\%). In addition, these data also show that sizeable proportions of Quebecers have either "no confidence at all" or "not a lot of confidence" in their core government institutions.

Remark however, that there are some notable discrepancies in these basic patterns when we observe the proportions that have "no confidence at all" or "not a lot of confidence". For example, on average, Quebecers display less confidence across levels in their governments (41\%) and parties (44\%) than in their legislatures (34\%) and civil service (30\%). Also, note that these data clearly demonstrate that Quebecers are far less confident in their federal government (55\%) and parties (51\%) than in their provincial (government: 33\%, parties: 40\%) or municipal (government: 35\%, parties: 43\%) counterparts. Moreover, the findings relating to legislatures indicate that, when observing the proportion with "some" or "a lot" of confidence, Quebecers have more confidence in their provincial legislature, the National Assembly (69\%) than in either the federal Parliament (63\%) or in their municipal councils (61\%). And, contrary to the rest, when it comes to the civil service, the evidence, suggests that there is very little variation in Quebecers' views across different levels of government.

Table 5 presents Quebecers' broader outlooks toward the overall "workings of democracy". Similar to their assessments of political authorities and core government institutions, these data also point to a familiar pattern. More specifically, very few Quebecers indicate that they are "very satisfied" with the workings of democracy, either provincially (13\%), federally (10\%) or municipally (14\%). Most Quebecers feel no more than "fairly satisfied" with the way that democracy works in their province (85\%), federally (88\%) or in their city/town (84\%). And many respondents indicate that they are either "not satisfied at all" or "not very satisfied" with the way that democracy works in Quebec (31\%), in the entire country (48\%) or in their municipality (29\%).

Given what these findings suggest about Quebecers' evaluations of their political authorities, government institutions and the overall workings of their various political systems, it is certainly plausible that these factors 
Table 4. Specific support—Quebecers’ evaluations of core governmental institutions.

\begin{tabular}{|c|c|c|c|c|c|}
\hline & $\begin{array}{c}\text { No confidence } \\
\text { at all }\end{array}$ & $\begin{array}{l}\text { Not a lot of } \\
\text { confidence }\end{array}$ & $\begin{array}{c}\text { Some } \\
\text { confidence }\end{array}$ & $\begin{array}{l}\text { A Lot of } \\
\text { confidence }\end{array}$ & $\mathrm{n}$ \\
\hline \multicolumn{6}{|l|}{ Government } \\
\hline Provincial & $7 \%$ & $26 \%$ & $54 \%$ & $11 \%$ & 993 \\
\hline Federal & $19 \%$ & $36 \%$ & $35 \%$ & $9 \%$ & 1.001 \\
\hline Municipal & $9 \%$ & $26 \%$ & $50 \%$ & $13 \%$ & 995 \\
\hline Cross-level average & $12 \%$ & $29 \%$ & $46 \%$ & $11 \%$ & \\
\hline \multicolumn{6}{|l|}{ Parties } \\
\hline Provincial & $7 \%$ & $33 \%$ & $55 \%$ & $3 \%$ & 1.002 \\
\hline Federal & $10 \%$ & $41 \%$ & $45 \%$ & $3 \%$ & 1.000 \\
\hline Municipal & $10 \%$ & $33 \%$ & $48 \%$ & $8 \%$ & 997 \\
\hline Cross-level average & $9 \%$ & $36 \%$ & $49 \%$ & $5 \%$ & \\
\hline \multicolumn{6}{|l|}{ Legislatures } \\
\hline Provincial (National Assembly) & $6 \%$ & $24 \%$ & $54 \%$ & $15 \%$ & 990 \\
\hline Federal (Parliament) & $7 \%$ & $28 \%$ & $50 \%$ & $13 \%$ & 998 \\
\hline Municipal (Municipal Council) & $7 \%$ & $31 \%$ & $51 \%$ & $10 \%$ & 995 \\
\hline Cross-level average & $7 \%$ & $28 \%$ & $52 \%$ & $13 \%$ & \\
\hline \multicolumn{6}{|l|}{ Civil Service } \\
\hline Provincial & $4 \%$ & $25 \%$ & $56 \%$ & $13 \%$ & 998 \\
\hline Federal & $6 \%$ & $26 \%$ & $54 \%$ & $13 \%$ & 996 \\
\hline Municipal & $7 \%$ & $22 \%$ & $56 \%$ & $13 \%$ & 1.000 \\
\hline Cross-level average & $6 \%$ & $24 \%$ & $55 \%$ & $13 \%$ & \\
\hline
\end{tabular}

Note: Questions: “Please indicate how much confidence you have in the following institutions?” Source: 2012 Quebec CPEP.

Table 5. Specific support-Quebecers' satisfaction with the workings of democracy.

\begin{tabular}{cccccc}
\hline & Not satisfied at all & Not very satisfied & Fairly satisfied & Very satisfied & $\mathrm{n}$ \\
\hline Quebec & $5 \%$ & $26 \%$ & $54 \%$ & $13 \%$ & 1.009 \\
Canada & $14 \%$ & $34 \%$ & $40 \%$ & $10 \%$ & 1.006 \\
City/Town & $7 \%$ & $22 \%$ & $55 \%$ & $14 \%$ & 1.005 \\
\hline
\end{tabular}

Questions: "On the whole, are you very satisfied, fairly satisfied, not very satisfied, or not at all satisfied with the way democracy works in?... QUEBEC/CANADA/CITY-TOWN? Source: 2012 Quebec CPEP.

may play at least some role in shaping how they feel about their respective democratic political communities overall. The data reported in the standardized linear regression models in Table 6 test this possibility by examining the combined effects of Quebecers' judgments of various specific political objects—political authorities, core government institutions and the workings of democracy overall—on how democratic they think their provincial, federal and municipal political communities are in practice. At the same time, this analysis also controls for a variety of additional factors that the literature suggests may be at play. For instance, given the ongoing relevance of the Charbonneau Commission in Quebec, it is quite possible that perceptions of the integrity of political authorities as well as levels of public cynicism might have important effects on people's assessments ofthe quality of democracy that they receive. For similar reasons, this analysis also controls for the effects of various other structural, cultural and contextual factors that are both theoretically and historically deemed as 
Table 6. Regression analysis-The determinants of evaluations of democracy in practice.

\begin{tabular}{|c|c|c|c|}
\hline Determinants & Provincial Level & Federal Level & Municipal Level \\
\hline Performance \& Integrity & B (SE) & B (SE) & B (SE) \\
\hline $\begin{array}{l}\text { Specific support (for political authorities, institutions, } \\
\text { and the workings of democracy) }\end{array}$ & $.46^{* * *}(.05)$ & $.61^{* * *}(.06)$ & $.55^{* * *}(.05)$ \\
\hline Integrity of political authorities (honest and ethical) & $.16^{* * *}(.04)$ & $.28^{* * *}(.05)$ & $.13^{* *}(.04)$ \\
\hline Cynicism (high) & $-.11^{* *}(.04)$ & $-.12^{* *}(.04)$ & $-.20^{* * *}(.04)$ \\
\hline \multicolumn{4}{|l|}{ Structural and cultural factors } \\
\hline Cognitive mobilization (high) & $.07(.04)$ & $.00(.04)$ & $.05(.04)$ \\
\hline Efficacy gap (high internal) & $-.06(.05)$ & $-.09(.05)$ & $-.07(.05)$ \\
\hline Media exposure (high) & $-.02(.05)$ & $-.09(.05)$ & $.03(.05)$ \\
\hline Post-materialist (vs. materialist) & $-.05^{*}(.02)$ & $.00(.02)$ & $-.03(.02)$ \\
\hline Deferential (high) & $.02(.02)$ & $.07^{* *}(.02)$ & $-.01(.02)$ \\
\hline Inter-personal trust (high) & $.02(.01)$ & $-.00(.01)$ & $-.01(.01)$ \\
\hline \multicolumn{4}{|l|}{ Contextual factors } \\
\hline Sex (female) & $-.00(.01)$ & $-.01(.01)$ & $-.00(.02)$ \\
\hline Nationalist & $.06^{* *}(.02)$ & $.05^{*}(.02)$ & $.03(.02)$ \\
\hline Federalist & $.05^{* *}(.02)$ & $.03(.02)$ & $.01(.02)$ \\
\hline English & $-.13^{* * *}(.02)$ & $-.09^{* * *}(.02)$ & $-.08^{* *}(.02)$ \\
\hline Allophone & $-.13^{* * *}(.04)$ & $-.02(.04)$ & $-.02(.04)$ \\
\hline Immigrant & $.03(.03)$ & $-.00(.02)$ & $.01(.03)$ \\
\hline Age (young) & $.03(.02)$ & $.02(.02)$ & $.00(.02)$ \\
\hline Income (high) & $-.00(.02)$ & $.03(.02)$ & $.01(.02)$ \\
\hline Constant & .41 & .22 & .40 \\
\hline $\mathrm{R}^{2}$ & .38 & .47 & .43 \\
\hline $\mathrm{n}$ & 834 & 841 & 838 \\
\hline
\end{tabular}

Note: ${ }^{*} p<.05 ;{ }^{* *} p<.01 ;{ }^{* * *} p<.001$. Source: 2012 Quebec CPEP.

relevant.

Note first that what Quebecers think about their political authorities, core government institutions and the workings of their municipal, provincial and federal democracies has very significant and robust consequences for how they evaluate the extent to which their various political systems are governed democratically in practice. More specifically, these data indicate that regardless of whether it is at the municipal, provincial or federal level, the more supportive Quebecers are of their specific political objects, the more likely they are to evaluate their respective democracies as being democratic in practice, even after taking into account a variety of alternative explanations. Note too, that these effects are sizably stronger at the federal and municipal levels than they are at the provincial level, but that relative to other determinants, these are clearly the most powerful predictors at all three levels of government.

Consider too that what Quebecers think about the integrity of their political authorities is also consistently relevant, but the effect is stronger at the federal level than at either the municipal or provincial levels. In all cases however, the findings are the same. The more honest and ethical political authorities are perceived to be, the more democratically Quebecers perceive their democracies to be governed in practice. Likewise, variations in cynical outlooks also have consistent effects. The more cynical Quebecers are about politics, the less likely 
they are to think that their political systems are democratic in practice. Also, not surprisingly given the timing and primary focus of the Charbonneau Commission, Quebecers' cynical outlooks have nearly two times the effect at the municipal level that they do at either the provincial or federal level.

Lastly, note that there are no structural or cultural factors exhibiting the same types of consistent and robust effects across all three levels of government. In terms of contextual factors, the most consistently significant evidence relates to language. In this case, the findings suggest that English speakers are less likely to view their municipal, provincial and federal political systems as being democratic than French-speaking Quebecers. Also, there is some consistent evidence at the provincial and federal levels that indicates that nationalists are more likely than those who would prefer an independent Quebec to view their provincial and federal democracies as being democratic in practice.

\section{Conclusion}

This investigation centers specifically on a component of the Canadian population and before more generalizable statements can be made with confidence about our results, this study needs to be replicated for other Canadian and non-Canadian populations. Nonetheless, these findings provide important baseline insights about the nuances in citizens' orientations toward democracy and how they may be affected by varying evaluations of political authorities, government institutions and the overall workings of different political systems. In addition, this analysis sheds some preliminary light on how political support can and does vary at the sub-state levelacross different levels of government, as well as for different types of government authorities and political institutions.

In all, there are three core sets of findings that emerge. The first pertains directly to outlooks toward democracy. Nearly all Quebecers believe that democracy in principle is a "good" way of governing the political community, regardless of whether it is at the federal, provincial or municipal level. Also, about three-quarters of these citizens are very firm in their views. However, our findings also show that many Quebecers are open to more than one regime possibility and that only small majorities are committed solely to a democratic regime alternative. Also noteworthy, our results indicate that only a small majority of Quebecers think their provincial political system comes close to working democratically in practice. And when asked about their federal and municipal systems, fewer than $50 \%$ of Quebecers believe that these are functioning democratically.

Secondly, in terms of "specific" support, the results of this investigation suggest that Quebecers vary considerably in their evaluations of political authorities, core government institutions and the overall workings of their political systems at the provincial, municipal and federal levels. The evidence also reveals consistent patterns across these objects at different levels of government. Very few Quebecers support their political authorities, core government institutions and the overall workings of their political systems whole heartedly and considerable proportions show little or no support. These findings also vary in several ways depending not only on the level of government but also on the types of political authorities and government institutions that are examined. For example, citizens tend generally to have greater confidence in their elected representatives than in their political leaders. Furthermore, Quebecers at least, have less confidence in their governments and political parties than they do in their legislatures and the civil service. Even more specifically, our evidence shows that Quebecers have less confidence in their federal government and political parties than they do in governments and parties at the provincial or municipal levels. Our data also suggest that Quebecers have more confidence in their provincial legislature than they do in Parliament or city councils. Finally, when observing evaluations of the workings of democracy overall, a substantial proportion of Quebecers are dissatisfied.

Thirdly, the findings from this study indicate that what Quebecers think about their political authorities, core government institutions and the workings of their municipal, provincial and federal democracies has significant and robust consequences when it comes to shaping evaluations of how democratic political systems are in practice- even after controlling for a variety of alternative explanations. The less supportive Quebecers are of their political authorities, government institutions and the workings of their respective political systems, the less likely they are to believe that their political communities are being governed democratically. While this particular analysis indicates that these determinants have more powerful effects at the federal and municipal levels than they do provincially, the overall implications are essentially the same. That is, these findings lend some preliminary support to the theoretical proposition which suggests that elevated dissatisfaction with "specific" political objects, especially if sustained over prolonged periods, may eventually detract from people's broader assessments of democracy—-particularly their evaluations of how democratic their political systems are in practice. 


\section{References}

Blais, A., \& Gidengil, E. (1991). Making Representative Democracy Work: The Views of Canadians. Research Studies. Ottawa: Royal Commission on Electoral Reform and Party Financing and Canada Communications Group, Supply and Services Canada and Dundurn Press.

CBC (2013). Quebec Hopes to End Era of Scandal with Municipal Elections. CBC News, November 3. http://www.cbc.ca/news/canada/montreal/quebec-hopes-to-end-era-of-scandal-with-municipal-elections-1.2350319

Chambers, S., \& Lenard, P. T. (2012). Reflections on the Democratic Deficit in Canada and the United States, In P. T. Lenard, \& R. Simeon (Eds.), Imperfect Democracies: The Democratic Deficit in Canada and the United States (pp. 315-329). Vancouver: UBC Press.

Clark, T. N., \& Rempel, M. (1997). Citizen Politics in Post-Industrial Societies. Urban Policy Challenges. Boulder: Westview Press.

Dalton, R. J. (2004). Democratic Challenges, Democratic Choices: The Erosion of Political Support in Advanced Industrial Democracies. Comparative Politics. New York: Oxford University Press.

Dalton, R. J. (2014). Citizen Politics: Public Opinion and Political Parties in Advanced Industrial Democracies. Washington: CQ Press.

Della Porta, D. (2000). Social Capital, Beliefs in Government, and Political Corruption. In S. J. Pharr, \& R. D. Putnam (Eds.), Disaffected Democracies: What's Troubling the Trilateral Countries? (pp. 202-27). Princeton: Princeton University Press.

Dogan, M. (2005). Political Mistrust and the Discrediting of Politicians. International Studies in Sociology and Social Anthropology. Leiden: Brill.

Easton, D. (1965). A Framework for Political Analysis. Englewood Cliffs: Prentice-Hall.

Hall, C. (2013). Chris Hall: Why the Mike Duffy Senate Scandal Still Perk-Olates. CBC News, May 31. http://www.cbc.ca/news/politics/chris-hall-why-the-mike-duffy-senate-scandal-still-perk-olates-1.1326363

Howe, P., Johnston, R., \& Blais, A. (2005). Strengthening Canadian Democracy. Montreal: Institute for Research on Public Policy.

Inglehart, R. (1990). Culture Shift in Advanced Industrial Society. Princeton, NJ: Princeton University Press.

Inglehart, R. (1997). Modernization and Postmodernization: Cultural, Economic, and Political Change in 43 Societies. Princeton, NJ: Princeton University Press.

Inglehart, R. (2007). Postmaterialist Values and the Shift from Survival to Self-Expression Values. In R. J. Dalton, \& H. Klingemann (Eds.), Oxford Handbook of Political Behavior (pp. 223-239). New York: Oxford University Press.

Inglehart, R., \& Welzel, C. (2005). Components of a Pro-Democratic Civic Culture. In Modernization, Cultural Change, and Democracy. Cambridge: Cambridge University Press.

Kanji, M., \& Tannahill, K. (2014). Support for Political Leaders and Elected Representatives in Quebec. Journal of Political Science and Public Affairs, 2, 116.

Kanji, M., Bilodeau, A., \& Scotto, T. J. (2012). The Canadian Election Studies: Assessing Four Decades of Influence. Vancouver: UBC Press.

Klingemann, H. D. (1999). Mapping Political Support in the 1990s: A Global Analysis. In P. Norris (Ed.), Critical Citizens: Global Support for Democratic Government (pp. 31-56). New York: Oxford University Press. http://dx.doi.org/10.1093/0198295685.003.0002

Kornberg, A., \& Clarke, H. D. (1992). Citizens and Community: Political Support in a Representative Democracy. New York: Cambridge University Press.

Lenard, P. T., \& Simeon, R. (2012). Imperfect Democracies: The Democratic Deficit in Canada and the United States. Vancouver: UBC Press.

Nevitte, N. (1996). The Decline of Deference: Canadian Value Change in Cross-National Perspective. Peterborough: Broadview Press.

Nevitte, N. (2002). Introduction: Value Change and Reorientation in Citizen-State Relations. In N. Nevitte (Ed.), Value Change and Governance in Canada (pp. 3-35). Toronto: University of Toronto Press.

Nevitte, N., \& Kanji, M. (2002). Authority Orientations and Political Support: A Cross-National Analysis of Satisfaction with Governments and Democracy. Comparative Sociology, 1, 387-412. http://dx.doi.org/10.1163/156913302100418655

Nevitte, N., \& White, S. (2012). Citizen Expectations and Democratic Performance: The Sources and Consequences of Democratic Deficits from the Bottom up. In P. T. Lenard, \& R. Simeon (Eds.), Imperfect Democracies: The Democratic Deficit in Canada and the United States (pp. 51-76). Vancouver: UBC Press.

Newton, K., \& Norris, P. (2000). Confidence in Public Institutions: Faith, Culture, or Performance? In S. J. Pharr, \& R. D. Putnam (Eds.), Disaffected Democracies: What's Troubling the Trilateral Countries? (pp. 52-73). Princeton, NJ: Princeton University Press. 
Norris, P. (1999). Critical Citizens: Global Support for Democratic Government. New York: Oxford University Press. http://dx.doi.org/10.1093/0198295685.001.0001

Norris, P. (2000). A Virtuous Circle? The Impact of Political Communications in Post-Industrial Democracies. Cambridge: Cambridge University Press.

Norris, P. (2011). Democratic Deficit: Critical Citizens Revisited. New York: Cambridge University Press. http://dx.doi.org/10.1017/CBO9780511973383

Norris, P. (2012). The Democratic Deficit: Canada and the United States in Comparative Perspective. In R. Simeon, \& P. T. Lenard (Eds.), Imperfect Democracies: The Democratic Deficit in Canada and the United States (pp. 23-50). Vancouver: UBC Press.

Payton, L. (2013). Senate Scandal Puts Harper’s Brand at Risk, Poll Suggests. CBC News, 1 November. http://www.cbc.ca/news/politics/senate-scandal-puts-harper-s-brand-at-risk-poll-suggests-1.2304444

Pharr, S. J. (2000). Officials’ Misconduct and Public Distrust: Japan and the Trilateral Democracies. In S. J. Pharr, \& R. D. Putnam (Eds.), Disaffected Democracies: What's Troubling the Trilateral Countries? (pp. 173-201). Princeton, NJ: Princeton University Press.

Putnam, R. D. (2000). Bowling Alone: The Collapse and Revival of American Community. New York: Simon \& Schuster.

Smith, J., Queen's University (2009). The Democratic Dilemma: Reforming the Canadian Senate. Montreal: Institute of Intergovernmental Relations, School of Policy Studies, Queen’s University by McGill-Queen’s University Press.

Welzel, C. (2013). Freedom Rising: Human Empowerment and the Quest for Emancipation. New York: Cambridge University Press. http://dx.doi.org/10.1017/CBO9781139540919

Woods, A. (2014). Quebec’s Charbonneau Inquiry Poses Risks for Both Liberals and PQ, Former Anti-Corruption Czar Says. thestar.com, 24 March.

http://www.thestar.com/news/canada/2014/03/24/quebecs_charbonneau_inquiry_poses_risks_for_both_liberals_and_pq_a nticorruption_czar_says.html 
Scientific Research Publishing (SCIRP) is one of the largest Open Access journal publishers. It is currently publishing more than 200 open access, online, peer-reviewed journals covering a wide range of academic disciplines. SCIRP serves the worldwide academic communities and contributes to the progress and application of science with its publication.

Other selected journals from SCIRP are listed as below. Submit your manuscript to us via either submit@scirp.org or Online Submission Portal.
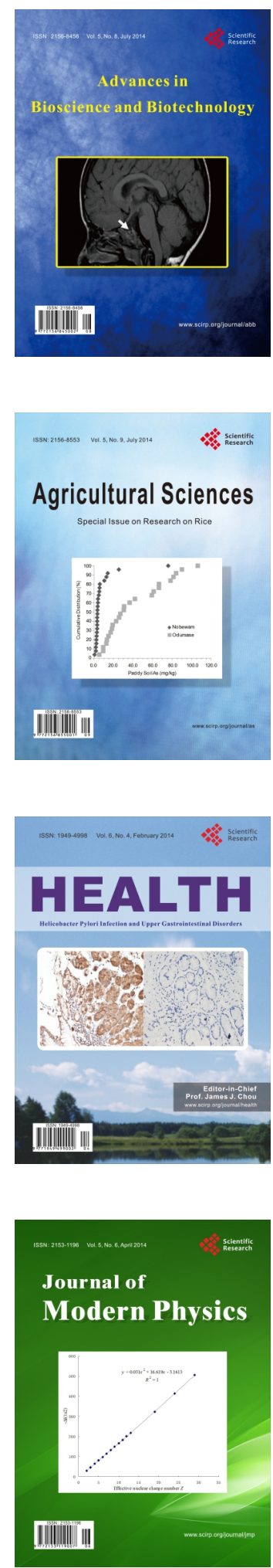
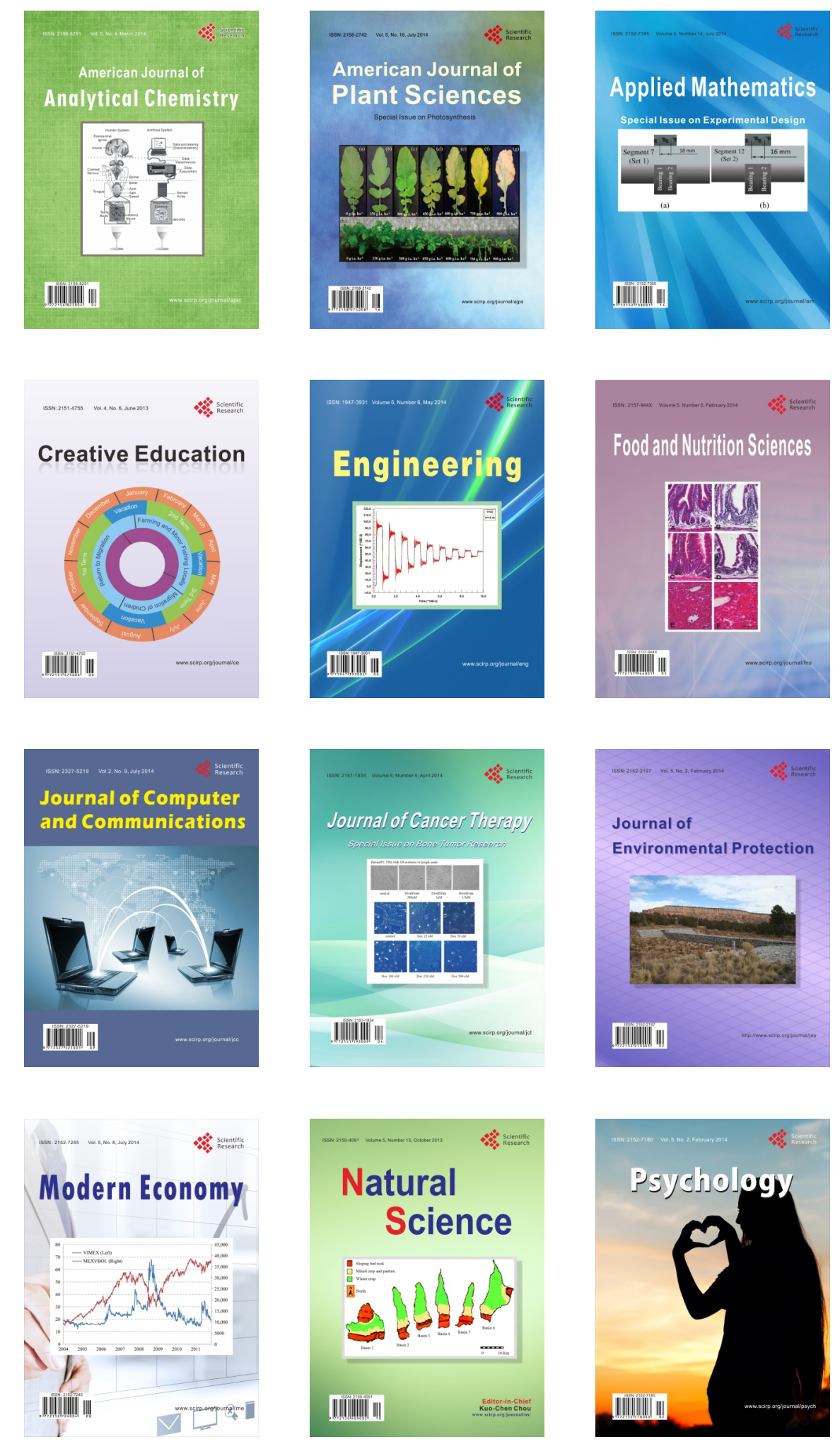